C. Kanam.-(1) The Committee, having examined the fragment of mandible, agrees that the appearance of this specimen is not inconsistent with the high antiquity assigned to it. (2) With the possible exceptions of the thickness of the symphysis, the conformation of the anterior internal surface, and what seems to be a large pulp-cavity of the first right molar tooth, the Committee is not able to point to any detail of the specimen that is incompatible with its inclusion in the type of the Homo sapiens. (3) In arriving at this conclusion the Committee has had regard to the conformation of the parts about the chin. It has noted that the incisor teeth show signs of crowding but has detected no indication of unusual size in the canine teeth.

\section{ARCH.AOLOGY}

The Archæological Committee, after examining the material exhibited, submitted the following conclusions :-

At Oldoway, in a continuous stratified deposit, which should henceforth rank as a standard section, a worked pebble industry in Bed I is supplemented in the lower part of II by an early Chellean industry with coup de poing and rostroid forms: and the pebble types persist for a while. There are indications of continuity and of a gradually evolving technique between the pebble industry and the Chellean technique. In Bed III the 'later' or 'evolved' Chellean passes on into highly evolved Acheulean industry, which becomes fully evolved in Bed IV. Though scraper types, round butt hand-axes, and flake implements occur, they are not dominant at any point in the series.

At Kanam and Kanjera, stratified deposits include a similar series of industries, and therein the Kanam jaw is associated with the pebble industry, and the Kanjera skull fragments with Chellean implements corresponding with those of the upper part of Oldoway II

The pebble industry of Oldoway I has no precise counterpart in western Europe, but is certainly anterior to the Early Chellean of Bed II. The Early Chellean culture of Bed II at Oldoway corresponds typologically with the industries of Early Pleistocene deposits in western Europe; and the uppermost industries of Oldoway IV with those of the Thames valley gravels with Acheulean implements. The types from Zambezi gravels and other deposits in South Africa indicate comparable lapse of time.

There is no reason to doubt that the series from East Africa is of at least equal antiquity with the European, and it may even begin somewhat earlier.

The Conference, after detailed discussion of these reports, and of supplementary information furnished by Dr. Leakey and Mr. MeInnes as to the circumstances of their discoveries, accepted the reports; congratulated Dr. Leakey on the exceptional significance of his discoveries; and expressed the hope that he may be enabled to undertake further researches, seeing that there is no field of archæological inquiry which offers greater prospects for the future. It especially urged the early organisation of another expedition.

The following were present and concurred in the above conclusions :-Sir Arthur Smith Woodward (chairman), A. L. Armstrong, H. Balfour, Miss D. M. A. Bate, P. G. H. Boswell, M. C. Burkitt, V. G. Childe, L. C. G. Clarke, W. L. H. Duckworth, H. J. Fleure, C. Forster Cooper, V. E. Fuchs, A. C. Haddon, A. T. Hopwood, O. T. Jones, Sir Albert Kitson, L. S. B. Leakey, D. McInnes, E.. H. Minns, J. Reid Moir, J. L. Myres, T. G. Mollison, F. Oswald, K. S. Sandford, R. A. Smith, W. J. Sollas, J. D. Solomon, Miss M. L. Tildesley and D. M. S. Watson.

\title{
Utilisation of Coal
}

$\mathrm{M}^{\mathrm{n}}$ R. H. T. TIZARD, rector of the Imperial College of Science and Technology, presided at a symposium on the utilisation of coal arranged by the British Science Guild and held at the Royal Institution on March 27. The large audience, which was representative of coal, coal-gas and oil interests, scientific and technical societies, trade unions and members of Parliament, was addressed by Capt. Bernard Acworth, Mr. Stephen Lacey, Eng. RearAdmiral W. Scott-Hill, and Mr. A. C. Hardy, after which there was a discussion.

In his opening paper on the "Economic Significance of Coal", Capt. Acworth made special reference to legislative differentiation unfavourable to the expansion of the coal and coal-gas industries. $\mathrm{He}$ asserted that the chief consumers of oil fuel are heavily subsidised out of the public purse. The British taxpayer pays most of the cost of maintaining aircraft, passenger and goods traffic: the taxpayer has likewise had to pay $£ 1,600,000,000$ to make our roads fit for motor traffic, and part of this vast sum is an indirect subsidy to the oil companies as it is spent on oil residuals. In addition, certain public authorities have made compulsory the use of electricity for lighting and heating purposes in subsidised houses.

Although the demand for fuel has greatly increased during the past twenty years, the output of coal in Great Britain has decreased by $67,000,000$ tons a year since 1913, this decrease indicating the extent by which imported oil has replaced coal. This replacement is represented over the period by an unfavourable trade balance of $£ 960,000,000$; and one million unemployed involving an annual public burden of $£ 65,000,000$. These facts, he urged, should be taken into account by our legislators in considering the relative costs and advantages of coal and oil as a fuel.

Mr. Stephen Lacey, who dealt with the "Development of the Use of Gas", claimed that the part played by the gas industry as an instrument in the efficient utilisation of coal is invariably under-rated. The carbonising process in gas and coke-oven works is the most efficient known means of converting coal into smokeless fuel and other convenient forms of heat. One ton of coal carbonised in a gas works will supply the same amount of useful heat as two tons of raw coal used either for direct heating or converted into electric energy, but at present only ten per cent of the total amount of coal used in Great Britain is carbonised in gas works as compared with twenty-five per cent of raw coal burnt for domestic purposes. This is indicative of the conservatism which has to be overcome, but progress is being made.

The use of gas for industrial undertakings is 
increasing, more than half the output of some supply companies being thus utilised: and quite recently successful demonstrations have been made in the use of cylinders of compressed gas for mechanical road vehicles, which opens up a new field of enterprise for the gas industry, for gas possesses advantages over petrol, particularly in connexion with enginestarting and completeness of combustion. The present need is for industrialists to overcome their bias in favour of oil and to modernise their plants to enable them to take advantage of the greater heat efficiency and lower cost of carbonised coal and coalgas.

In his paper on "Coal for Sea Transport", RearAdmiral Scott-Hill expressed the view that the use of coal for sea transport must be determined by various factors, only one of which is the actual cost per heat unit of coal as compared with oil. The material we import is greater in bulk than that which we export, and therefore a double economy is effected if our ships carry a home-produced fuel as a source of heat or 'bunkers'. This was the factor which led to the supremacy of the British mercantile marine in the nineteenth century, but it was accompanied by standardisation of ship machinery and a reluctance to apply the results of modern science by designers of ship engines. Consequently the first oil-fired ships worked at an advantage over the stoker-fed coalburning ships, in addition to which the use of oil makes it possible to reduce greatly the number of firemen, it is clean and its 'bunkering' can be carried out more rapidly and without interfering with other work in and about the ship-great advantages for passenger ships and the Navy. For example, at full-speed a first-class battleship would need 600 stokers if raw coal were used against 200 required for an oil-burning ship. Nevertheless, if modern methods of feeding furnaces are adopted by coalburning ships, if fuller advantage is taken of pulverised coal or mixed fuels, and if the Government encourages the better utilisation of coal, there is still a future for the use of coal in sea transport.

Mr. A. C. Hardy claimed that, if the wish of the back-to-coal enthusiasts were realised, the British mercantile marine would probably be swept out of economic existence by sheer weight of the operating superiority of its rivals. The inference to be drawn from the great increase in oil-burning and motor ships must be that they have advantages for certain purposes over coal-burning ships. Since 1914, the world tonnage of oil ships has grown from $1 \frac{1}{2}$ million tons to nearly $20 \frac{1}{2}$ million tons: the motor ships from $\frac{1}{4}$ million to 10 million tons. In the past ten years, however, in spite of the fact that the tonnage of oil ships has doubled, that of coal-burning ships has decreased from $45 \frac{1}{2}$ million to 40 million tons.

In any event, the ultimate criterion must be the reduction of fuel cost, to which problem both marine coal-steam and marine oil-steam designers are applying themselves with assiduity and success : both of these have also to reckon with the fuel figure of the marine Diesel designers. Coal consumption per horsepower hour has now been reduced to $1 \mathrm{lb}$. as compared with the best oil-steam figure of about $0.6 \mathrm{lb}$. and the best Diesel figure of $0 \cdot 35 \mathrm{lb}$. Oil now possesses the advantage that oil-filling stations are more numerous than coaling stations, in addition to the advantages over coal of cleanliness in use, quickness of 'bunkering', ease of stowage, small amount used, lower labour costs on board, and the smaller space occupied by oil-using plant. The real question, he suggested, is whether or not Great Britain is justified in creating a handicap against oil in favour of coal. This, he asserted, can only be done at great expense to the taxpayer and to the ultimate disadvantage of our mercantile marine.

In opening the discussion, Dr. E. F. Armstrong suggested that colliery owners on one hand and the Government on the other must be held partly responsible for the replacement of coal by coal-gas, electricity and oil as a heat source : the former by their tardy recognition of the need for modern methods of coalgetting, the cleaning and classification of coal, care in transport, and their acquiescence in wasteful and obsolete methods of distribution of coal for domestic use : the latter by the adoption of the quota system. Another factor in the decline in the use of coal is the attitude of the coal producers towards their natural allies, the gas and electricity supply companies, both of which are charged excessive prices for coal and both of which in turn add to their own costs a dispro. portionate and unnecessary burden of advertising charges. Finally, he suggested that Capt. Acworth's plea for a back-to-coal movement would be more effective if he supported instead of attacking expenditure on those researches directed towards obtaining oil from coal, including hydrogenation of coal.

Major F. A. Freeth added that if the coal producers had spent only a small fraction of what Imperial Chemical Industries Ltd. had spent on research and organisation they would not be in their present wretched plight.

Mr.H.Pirie, who followed, said that the coal industry has now realised the need for action on the lines suggested by Dr. Armstrong and Major Freeth. The Coal Utilisation Council which he represented was formed for the purpose of promoting the sale of coal, to which end an intensive propaganda campaign is to be launched. An information bureau has been set up from which both producers and consumers can obtain advice and information, including assistance on technical and scientific matters.

Admiral Willmott-Nicholson expressed his sympathy with the views of Capt. Acworth and laid stress on the strategic importance of Great Britain being independent of imports of fuel in the event of war. Among others who contributed to the discussion were Dr. Ormandy, Mr. Hamilton Gibson and Mr. Zulver.

In summing up, Mr. Tizard warned his audience against falling into the error of associating too closely our increasing imports of oil with the decrease in the use of coal and with unemployment among the mining population. The fact that less coal is now used for domestic consumption is obviously not unconnected with increased elficiency in its use, and taking a long view, this is an advantage to the nation. It is a melancholy reflection that whereas ten years ago our economists and politicians attributed our industrial stagnation to the failure of industrialists to apply science to their undertakings, they now attribute our economic depression to the success with which science has been applied in industry. The fact is that our industrial supremacy during the greater part of the nineteenth century was due to the skill and assiduity with which we applied science and invention to then existing conditions. It is useless to bemoan changed conditions : our task is still to apply our best scien. tific brains to the world as it is to-day. 